\title{
O MONITORAMENTO DE MOVIMENTAÇÃO FINANCEIRA NO COMBATE À LAVAGEM DE DINHEIRO E O DIREITO À INTIMIDADE E PRIVACIDADE
}

\author{
Maristela Gonçalves \\ http://buscatextual.cnpq.br/buscatextual/visualizacv.do?id=K4614047Y2
}

\begin{abstract}
Resumo: Em 03.03.1998 foi publicada no Brasil a Lei $\mathrm{n}^{\circ} 9.613$ que tipificou o crime de lavagem de dinheiro e criou, no âmbito do Ministério da Fazenda, o Conselho de Controle de Atividades Financeiras - Coaf. A Lei $\mathrm{n}^{\circ}$ 9.613/98 também atribuiu a pessoas jurídicas de diversos setores econômico-financeiros maior responsabilidade na identificação de clientes, na manutenção de registros de todas as operações e na comunicação de situações com indícios de crimes ao Coaf, sujeitando-as ainda às penalidades administrativas pelo descumprimento das obrigações. Os bancos, dentre outros, também estão sujeitos às obrigações impostas pela Lei $\mathrm{n}^{\circ}$ 9.613/98, e por isso têm o dever de comunicar ao Coaf situações consideradas indícios de crime, ou seja, situações que, por suas características, no que se referem às partes envolvidas, valores, forma de realização, instrumentos utilizados, ou pela falta de fundamento econômico ou legal, possam configurar indícios dos crimes previstos na Lei. Cabe aos bancos, por meio de uma área específica, fazer uma análise valorativa das transações e fatos realizados pelos clientes. Verifica-se assim, que o dever de monitorar a movimentação financeira do cliente e comunicar ao Coaf situações ou operações consideradas pela instituição como indícios de crime (atípicas ou suspeitas) colide com os direitos à intimidade e à vida privada do cliente que tem garantia constitucional de ter seu sigilo bancário preservado. De um lado está o interesse público de combater a criminalidade e de outro o interesse do cliente em ter o sigilo de suas informações financeiras protegido. Assim, no presente trabalho, será analisado o conceito de lavagem de dinheiro; preceitos da Lei $\mathrm{n}^{\circ}$ 9613/98, como a criação do Coaf (Conselho de Controle de Atividades Financeiras), quem são as pessoas sujeitas à Lei, a obrigatoriedade de identificação dos clientes, manutenção de registros e comunicação de operações financeiras com indícios de crime ao Coaf; bem como serão analisados os conceitos de sigilo bancário, intimidade e privacidade, trechos da Lei Complementar $\mathrm{n}^{\circ} 105$ e a problematização propriamente dita, ou seja, será estudado se a obrigatoriedade de monitoramento e comunicação de movimentação com indício de crime ao órgão regulador, imposta às instituições financeiras para o combate à lavagem de dinheiro, é considerada quebra ou transferência de sigilo bancário, se colide com os direitos à intimidade e privacidade do cliente e se o direito ao sigilo bancário é relativo, podendo ceder em face do princípio da supremacia do interesse público.
\end{abstract}

Palavras-chave: prevenção à lavagem de dinheiro - sigilo bancário - intimidade privacidade - supremacia do interesse público.

\section{Monitoring of Financial Transactions in the Combat of Money Laundering and the Right to Intimacy and Privacy}

Abstract: In March $3^{\text {rd }}, 1998$ the Law n. 9.613 that typified the crime of money laundering was published. This law also created the Controlling Counsel of Financial Activities (Coaf) under the Treasury Ministry. The law n. 9.613/98 also assigned to legal entities of various economic and financial sectors more responsibility on customer identification, on keeping record of registrations of all operations and on communication of the situations with evidence of crimes to the Coaf, even subjecting them to administrative penalties for the noncompliance 


\section{REVISTA ELETRÔNICA DA FACULDADE DE DIREITO DE FRANCA \\ $w w w . r e v i s t a . d i r e i t o f r a n c a . b r$ \\ v. 6, n.1, dez/2012, ISSN: 1983-4225}

of obligations. Banks, among others, are also subject to obligations imposed by Law $\mathrm{n}$. 9.613/98, and therefore have a duty to communicate the Coaf situations considered evidence of crime, i.e., situations that, by their characteristics with relation to stakeholders, values, embodiment, instruments used, or the lack of economic or legal foundation, may constitute evidence of the crimes defined in law. It is up to the banks, through a specific area, to make an evaluative analysis of the facts and transactions conducted by customers. It thus appears that the duty to monitor the financial transactions of the customer and communicate Coaf about situations or transactions considered by the institution as evidence of crime (atypical or suspicious) collides with the rights to privacy and the private life of the client that has a constitutional guarantee of having his banking data preserved. On one side is the public interest in combating crime and on the other is the customer interest in having the confidentiality of his financial information protected. Thus, the present study will analyze the concept of money laundering; provisions of Law n. 9613/98, such as the creation of COAF (Controlling Counsel of Financial Activities), who are the persons subject to the law, the obligation of identifying customers, record keeping and reporting of financial transactions with evidence of crime to Coaf; it will also consider the concepts of banking secrecy, intimacy and privacy, excerpts of Complementary Law n. 105 and the problematization itself, i.e. it will be studied whether the mandatory monitoring and reporting of transactions with evidence of crime to the regulator organ, imposed on financial institutions to combat money laundering, is considered breach or transfer of bank secrecy, if it collides with the customer rights of intimacy and privacy and if the right of banking secrecy is relative and may yield in the face of the supremacy of public interest principle.

Keywords: prevention of money laundering, bank secrecy, intimacy, privacy, supremacy of public interest

\section{INTRODUÇÃO}

A lavagem de dinheiro tem reclamado atualmente a atenção de toda a sociedade diante do alto grau de sofisticação das atividades criminosas.

Tema de alta relevância e que envolve interesses transnacionais, o combate à lavagem de dinheiro é objeto de diversos instrumentos internacionais e regionais, como o Grupo de Egmont, GAFI/FATF, GAFISUD, que, a princípio, subscreveram, documentos de recomendação para tipificação do crime de lavagem de dinheiro, bem como a criação de órgão responsável pelo combate a esse delito.

Em 03.03.1998, o Brasil, dando continuidade a compromissos internacionais assumidos a partir da assinatura da Convenção de Viena de 1988, aprovou a Lei $\mathrm{n}^{\mathbf{0}}$ 9.613, posteriormente alterada pelas Leis $\mathrm{n}^{\mathrm{o}}$ 10.467, de 11.06.2002, e 10.701, de 09.07.2003.

A Lei $n^{\circ}$ 9.613/98 tipificou o crime de lavagem de dinheiro e criou, no âmbito do Ministério da Fazenda, o Conselho de Controle de Atividades Financeiras - Coaf, com a finalidade de disciplinar, aplicar penas administrativas, receber, examinar e identificar as 


\section{REVISTA ELETRÔNICA DA \\ FACULDADE DE DIREITO DE FRANCA \\ $w w w . r e v i s t a . d i r e i t o f r a n c a . b r$ \\ v. 6, n.1, dez/2012, ISSN: 1983-4225}

ocorrências suspeitas de atividades ilícitas previstas na Lei, sem prejuízo da competência de outros órgãos e entidades (Bacen, Susep, CVM e SPC).

A norma supracitada também atribuiu às pessoas jurídicas de diversos setores econômico-financeiros maior responsabilidade na identificação de clientes, na manutenção de registros de todas as operações e na comunicação de situações com indícios de crimes, sujeitando-as ainda às penalidades administrativas pelo descumprimento das obrigações.

A Lei ordena que as pessoas obrigadas, dentre elas os bancos, deverão comunicar aos órgãos competentes operações que possam constituir-se em sérios indícios dos crimes de tráfico ilícito de substâncias entorpecentes ou drogas afins; terrorismo e seu financiamento; contrabando ou tráfico de armas, munições ou material destinado à sua produção; extorsão mediante seqüestro; contra a Administração Pública, inclusive a exigência, para si ou para outrem, direta ou indiretamente, de qualquer vantagem, como condição ou preço para a prática ou omissão de atos administrativos; contra o sistema financeiro nacional; praticado por organização criminosa; e praticado por particular contra a administração pública estrangeira.

Para cumprir tal determinação e não sofrer as sanções previstas, os bancos desenvolveram ou adquiriram softwares capazes de verificar na movimentação financeira do cliente situações consideradas indícios de crime, conforme as orientações do Banco Central do Brasil, levando em conta renda, atividade econômica, perfil e capacidade financeira presumida do cliente.

O presente artigo busca discutir se o monitoramento da movimentação financeira dos clientes de uma instituição bancária, e a consequente comunicação ao Coaf de situações ou operações consideradas pela instituição como indícios de crime (atípicas ou suspeitas) colide com os direitos à intimidade e à vida privada do cliente.

\section{LAVAGEM DE DINHEIRO: CONCEITO E ORIGEM}

Conforme definição trazida pelo Coaf (Conselho de Controle de Atividades Financeiras), "o crime de lavagem de dinheiro caracteriza-se por um conjunto de operações comerciais ou financeiras que buscam a incorporação na economia de cada país, de modo transitório ou permanente, de recursos, bens e valores de origem ilícita e que se desenvolvem 


\section{REVISTA ELETRÔNICA DA FACULDADE DE DIREITO DE FRANCA \\ www.revista.direitofranca.br \\ v. 6, n.1, dez/2012, ISSN: 1983-4225}

por meio de um processo dinâmico que envolve, teoricamente, três fases independentes que, com freqüência, ocorrem simultaneamente." 1

Rodolfo Tigre Maia assim define a lavagem de dinheiro:

pode ser simplificadamente compreendida, sob uma perspectiva teleológica e metajurídica, como o conjunto complexo de operações, integrado pelas etapas de conversão (placement), dissimulação (layering) e integração (integration) de bens, direitos e valores, que tem por finalidade tornar legítimos ativos oriundos da prática de atos ilícitos penais, mascarando esta origem para que os responsáveis possam escapar da ação repressiva da justiça. ${ }^{2}$

As três fases citadas são:

- Colocação (Placement) - etapa em que o criminoso introduz o dinheiro de origem ilícita no sistema financeiro. Exemplo: depósito de valores em espécie em conta bancária ou compra de objetos de grande valor em espécie (obras de arte, jóias, imóveis).

- Ocultação (Layering) - consiste em distanciar os fundos ilícitos de sua fonte, em dificultar o rastreamento dos valores de origem ilícita, através de uma série de transações como transferências de fundos por meios eletrônicos para contas de diversas instituições financeiras ou para os chamados paraísos fiscais.

- Integração (Integration) - consiste no reingresso, na integração formal dos recursos de origem ilícita no sistema econômico, para dar aparência de legitimidade, como por exemplo através da compra de imóveis, investimentos em projetos comerciais, etc. ${ }^{3}$

A expressão lavagem de dinheiro teria surgido na década de 20, nos Estados Unidos. Naquela época, as quadrilhas que visavam transformar o dinheiro obtido de forma ilícita em dinheiro "legal", de forma que passasse a integrar a economia formal, o faziam através de empresas de fachada, com giro rápido de dinheiro. A maioria desses criminosos se utilizava de lavanderias e lava - rápidos, o que possibilitava a inclusão do dinheiro "sujo" juntamente com o dinheiro obtido legalmente. ${ }^{4}$

Segundo Edson Pinto:

diversas teorias tentam explicar a origem da metodologia da lavagem de valores. A mais aceita propugna que Meyer Lansky, gangster americano e financista, no início da década de 1960, descobriu

1 https://www.coaf.fazenda.gov.br/conteudo/sobre-lavagem-de-dinheiro-1. Sobre Lavagem de Dinheiro. O que é. Acesso em 12/04/2010.

2 Lavagem de Dinheiro. $2^{\circ}$ Edição. São Paulo: Malheiros Editores, 2007, p. 53

3 http://www.lavadodinero.com/QueEsLavado/QueEsLavado_Etapas.aspx. . Que es lavado de dinero. Acesso em 12/04/2010.

4 LILLEY, Peter. Lavagem de dinheiro: negócios ilícitos transformados em atividades legais. São Paulo: Futura, 2001, p.16 


\section{REVISTA ELETRÔNICA DA FACULDADE DE DIREITO DE FRANCA \\ www.revista.direitofranca.br \\ v. 6, n.1, dez/2012, ISSN: 1983-4225}

que a melhor maneira de ocultar ativos ilegais seria colocar o dinheiro fora do alcance das autoridades de seu país, ou seja, arranjar uma jurisdição que não cooperasse com os Estados Unidos para o seu confisco e restituição, e a Suíça foi um dos primeiros destinos escolhidos, além de implantar uma rede de lavandeiras para mesclar o dinheiro legítimo com o capital obtido ilicitamente. ${ }^{5}$

Ainda de acordo com Edson Pinto, também não é possível afirmar quando o termo "lavagem de dinheiro" foi empregado pela primeira vez. Acredita-se que tenha sido durante o caso Watergate, nos EUA, em meados da década de 70. Entretanto, documentos confirmam que em 1982 um tribunal americano usou oficialmente a expressão "money laundering”, para denunciar a ocultação de bens provenientes do trafico de cocaína colombiana. A expressão passou a ser aceita e difundida pela impressa dos EUA. ${ }^{6}$

\subsection{Instrumentos e Ações Internacionais}

O avanço tecnológico e a globalização da economia criaram condições para o surgimento de novas atividades propiciando o surgimento da chamada delinquiência internacional e a criminalidade organizada que prosperaram nos setores que envolvem grandes quantidades de recursos econômicos, como, por exemplo, atividades vinculadas ao tráfico de armas, drogas e pessoas.

O crime organizados necessita de meios para dar aparência licita aos recursos obtidos de forma ilícita, assim tornou-se indispensável a previsão de medidas administrativas e político-criminais. A comunidade internacional, por meio de organismos internacionais e regionais, subscreveu vários instrumentos jurídicos recomendando a diversos países a implementação de normas que tipifiquem o delito de lavagem de dinheiro e a criação de órgão responsável pela adequada persecução. ${ }^{7}$

Dentre os diversos grupo e comitês internacionais (Comitê de Basiléia, Grupo de Egmont, Grupo de Wolfsberg, Diretivas da União Européia, etc), destaca-se o Grupo de Ação Financeira - Financial Action Task Force on Money Laundering (GAFI/FATF). Em resposta à crescente preocupação sobre a lavagem de capitais, reconhecendo a ameaça ao sistema bancário e às instituições financeiras, em 1988 o G-7 (sete países mais ricos do mundo) no âmbito da OCDE (Organização para a Cooperação e Desenvolvimento Econômico) criou o GAFI/FATF.

5 Lavagem de Capitais e Paraísos Fiscais. São Paulo: Atlas, 2007, p.86

6 Idem.Ibidem, p.87

7 DE SANCTS, Fausto Martin. Combate à Lavagem de Dinheiro. Campinas/SP: Millenium Editora, 2008, p.1 


\section{REVISTA ELETRÔNICA DA \\ FACULDADE DE DIREITO DE FRANCA \\ $w w w . r e v i s t a . d i r e i t o f r a n c a . b r$ \\ v. 6, n.1, dez/2012, ISSN: 1983-4225}

O Grupo de Ação Financeira (GAFI) é um órgão inter-governamental cujo objetivo é o desenvolvimento e a promoção de políticas nacionais e internacionais de combate à lavagem de capitais e financiamento do terrorismo. O GAFI é um "órgão de decisão política" que trabalha para gerar a necessária vontade política para realizar as reformas legislativas e regulamentares nestas áreas.

Em 1990 redigiu 40 Recomendações, em 2003 foram redigidas mais oito referentes ao financiamento do terrorismo, e em 2004 foi editada a $9^{\circ}$ Recomendação Especial para reforçar as normas internacionais sobre lavagem de dinheiro e financiamento do terrorismo. Tais recomendações não possuem força vinculante, mas exercem forte influência internacional.

Hoje o GAFI conta com 35 membros, sendo 33 países, dentre eles o Brasil, e duas organizações. A Índia tornou-se país observador em 2006 está se organizando para se tornar membro. ${ }^{8}$

Para se tornar um membro do GAFI é necessário: ser estrategicamente importante, ser membro de um organismo regional, criminalizar a lavagem de dinheiro e o financiamento do terrorismo, estabelecer uma Unidade de Inteligência Financeira, apresentar carta comprometendo-se a implementar as 40 recomendações e as nove recomendações especiais do Grupo dentro de um prazo razoável de tempo. ${ }^{9}$

\section{COMBATE À LAVAGEM DE DINHEIRO NO BRASIL - LEI Nº.613/98}

Dando continuidade a compromissos assumidos a partir da Convenção de Viena de 1988, o Brasil, em março de 1998, publicou a Lei $\mathrm{n}^{\circ}$ 9.613, posteriormente alterada pelas Leis $\mathrm{n}^{\mathrm{o}} 10.647 / 02$ e 10.701/03, que dispõe sobre os crimes de "lavagem" ou ocultação de bens, direitos e valores; a prevenção da utilização do sistema financeiro para os ilícitos previstos nesta Lei; cria o Conselho de Controle de Atividades Financeiras - Coaf, e dá outras providências.

A Lei $n^{\circ} 9.613 / 98$ traz em seu artigo $1^{\circ}$ o rol taxativo de crimes antecedentes à lavagem de dinheiro, ou seja, estará configurado tal crime se o individuo "ocultar ou dissimular a natureza, origem, localização, disposição, movimentação ou propriedade de bens, direitos ou valores provenientes, direta ou indiretamente, de crime: de tráfico ilícito de

8 http://www.fatf-gafi.org/pages/0,3417,en_32250379_32236869_1_1_1_1_1,00.html. Members and Observers. Acesso em 21/04/2010.

9 Guía de Estudio para El Exame de Certificación CAMS - Cuarta Edición - Publicación de la ACAMS. 


\section{REVISTA ELETRÔNICA DA FACULDADE DE DIREITO DE FRANCA \\ $w w w . r e v i s t a . d i r e i t o f r a n c a . b r$ \\ v. 6, n.1, dez/2012, ISSN: 1983-4225}

substâncias entorpecentes ou drogas afins; de terrorismo e seu financiamento; de contrabando ou tráfico de armas, munições ou material destinado à sua produção; de extorsão mediante seqüestro; contra a Administração Pública, inclusive a exigência, para si ou para outrem, direta ou indiretamente, de qualquer vantagem, como condição ou preço para a prática ou omissão de atos administrativos; contra o sistema financeiro nacional; praticado por organização criminosa; praticado por particular contra a administração pública estrangeira (arts. 337-B, 337-C e 337-D do Decreto-Lei n⿳⺈ 2.848, de 7 de dezembro de 1940 - Código Penal).

Como mencionado anteriormente, a Lei criou também o Coaf (Conselho de Controle de Atividades Financeiras), Unidade de Inteligência Financeira Brasileira (Financial Intelligence Unit - FIU), conforme definição do Grupo de Egmont é a agência nacional central responsável por receber e requerer, analisar e distribuir às autoridades competentes as denúncias sobre as informações financeiras com respeito a procedimentos presumidamente criminosos conforme legislação ou normas nacionais para impedir a lavagem de dinheiro. ${ }^{10}$

Estas FIUs podem ser de natureza judicial, policial, mista (judicial/policial) ou administrativa. O Brasil adotou o modelo administrativo. ${ }^{11}$

O Coaf foi criado pela Lei $n^{\circ}$ 9.613/98 no âmbito do Ministério da Fazenda, com a finalidade de disciplinar, aplicar penas administrativas, receber, examinar e identificar as ocorrências suspeitas de atividades ilícitas previstas na Lei. Tem, ainda, como dever coordenar e propor mecanismos de cooperação e de troca de informações que viabilizem ações rápidas e eficientes no combate à ocultação ou dissimulação de bens, direitos e valores e requerer aos órgãos da Administração Pública as informações cadastrais bancárias e financeiras de pessoas envolvidas em atividades ilícitas.

Além das funções típicas de uma UIF, o Coaf regula os setores obrigados que não contam com órgão supervisor próprio, tais como as empresas de fomento mercantil factoring -, comerciantes de obras de arte e antiguidades, de jóias e metais preciosos, sorteios, cartões de crédito, etc.

A estrutura do Coaf é composta pelos seguintes órgãos: Presidência, Plenário e Secretaria Executiva. O quadro de profissionais, de aproximadamente quarenta pessoas, compõem-se servidores de diversas carreiras públicas do Ministério da Fazenda e de outros órgãos e entidades públicas.

10 http://www.egmontgroup.org/about/what-is-an-fiu. What is a FIU?. Acesso em 15/05/2010

11 DE SANCTS, Fausto Martin. Op. Cit., p.26 


\section{REVISTA ELETRÔNICA DA FACULDADE DE DIREITO DE FRANCA \\ $w w w . r e v i s t a . d i r e i t o f r a n c a . b r$ \\ v. 6, n.1, dez/2012, ISSN: 1983-4225}

Após receber e analisar as informações suspeitas de atividades ilícitas, se concluir pela existência de crimes previstos na Lei $\mathrm{n}^{\circ}$ 9.613/98, de fundados indícios de sua prática, ou de qualquer outro ilícito, o Coaf comunicará às autoridades competentes (Polícia Federal e Ministério Público) para a instauração dos procedimentos cabíveis. O Coaf tem acesso a dados de clientes de instituições financeiras públicas e privadas, num modelo semelhante ao norte-americano, Financial Crimes Enforcement Network (FINCEN). ${ }^{12}$

O Sistema de Informações do Coaf - SISCoaf, recebe, integra e trata diversas bases de dados, contando, ainda, com outras modernas ferramentas de análise de dados, tais como I2 e Visualinks. Dentre as fontes de informações utilizadas pelo Coaf, pode-se citar: Rede Infoseg (base de inquéritos), Cadastro de Pessoas Físicas - CPF, Cadastro Nacional de Pessoas Jurídicas - CNPJ, Declaração de Operações Imobiliárias - DOI, Sistema Integrado de Administração de Recursos Humanos - SIAPE, Sistema de Informações Rurais - SIR, Cadastro Nacional de Informações Sociais - CNIS, Cadastro Nacional de Empresas - CNE, Análise das Informações de Comércio Exterior - Alice Web - Base de Grandes Devedores da União, Bases do TSE, dentre outras. Todas essas bases representam importantes instrumentos na produção de inteligência financeira pelo Coaf.

Por meio do cruzamento das informações recebidas dos setores obrigados com os dados disponíveis nas bases citadas, são detectados sinais de alerta, que propiciam a abertura de pastas virtuais (casos) para aprofundamento da análise e elaboração de Relatórios de Inteligência Financeira - RIF. Ao ser concluído, o RIF é submetido às instâncias internas, para avaliação e decisão pelas alçadas adequadas, sendo, ao final, disponibilizado às autoridades competentes, por meio do Sistema Eletrônico de Intercâmbio - SEI, ou fisicamente, quando for o caso, com as devidas cautelas de segurança, garantindo a proteção da informação. ${ }^{13}$

\subsection{Das Pessoas Sujeitas à Lei no 9.613/98 (Art.9 ${ }^{\circ}$ )}

Estão sujeitas à Lei $n^{\circ}$ 9.613/98 as pessoas jurídicas elencadas no artigo $9^{\circ}$ da referida lei, como por exemplo: bancos, bolsas de valores de mercadorias ou futuros, as seguradoras, as corretoras de seguros e as entidades de previdência complementar ou de capitalização, as 


\section{REVISTA ELETRÔNICA DA \\ FACULDADE DE DIREITO DE FRANCA \\ www.revista.direitofranca.br \\ v. 6, n.1, dez/2012, ISSN: 1983-4225}

administradoras de cartões de credenciamento ou cartões de crédito, bem como as administradoras de consórcios para aquisição de bens ou serviços, factoring, etc

O controle desses setores é feito diretamente por seus órgãos reguladores próprios (autoridades competentes), através de regulamentos fixados (Bacen - Banco Central do Brasil; CVM - Comissão de Valores Mobiliários; Susep - Superintendência de Seguros Privados; e SPC - Secretária de Previdência Complementar). A Lei determina que as instruções destinadas às pessoas mencionadas no artigo $9^{\circ}$, para as quais não exista órgão próprio fiscalizador ou regulador, serão expedidas pela Coaf.

Conforme dispõe o artigo 12, as autoridades competentes deverão aplicar, cumulativamente ou não, às pessoas taxadas no artigo $9^{\circ}$ da Lei $n^{\circ} 9.613 / 98$, bem como aos administradores das pessoas jurídicas, que deixarem de cumprir as obrigações previstas na Lei, as seguintes sanções administrativas: advertência; multa pecuniária variável; inabilitação temporária, pelo prazo de até dez anos, para o exercício do cargo de administrador das pessoas jurídicas referidas no art. $9^{\circ}$; e cassação da autorização para operação ou funcionamento.

\subsection{Da Comunicação de Operações Financeiras (Art. 11)}

Estabelece o artigo 11 da Lei $n^{\circ} 9.613 / 98$ a obrigação das pessoas citadas no artigo $9^{\circ}$ de informarem às autoridades competentes a cerca de atividades e operações (ou propostas) que possam apresentem sérios indícios de crime, cabendo a essas pessoas uma análise valorativa das transações e fatos realizados pelos clientes. ${ }^{14}$

Entretanto, as pessoas sujeitas à Lei não possuem competência para investigar a ocorrência de um crime, assim, a Lei determinou que cabe às autoridade competentes (no caso de bancos a autoridade competente é o Bacen) editarem relação de operações que, por suas características, no que se referem às partes envolvidas, valores, forma de realização, instrumentos utilizados, ou pela falta de fundamento econômico ou legal, possam configurar indícios dos crimes previstos na Lei.

Identificada situação que apresente indício de crime, a comunicação ao Coaf deverá ser realizada no prazo de vinte e quatro horas, sem que seja dada ciência aos clientes de tal ato. As comunicações de boa-fé não acarretam responsabilidade civil ou administrativa. A não

14 PINTO, Edson. Op. Cit., p.101 


\section{REVISTA ELETRÔNICA DA \\ FACULDADE DE DIREITO DE FRANCA \\ www.revista.direitofranca.br \\ v. 6, n.1, dez/2012, ISSN: 1983-4225}

comunicação das situações que apresentem indícios de crime pode acarretar a aplicação das sanções previstas no artigo 12.

Segundo Marco Antônio Barros:

para que a Lei de 'Lavagem possa efetivamente produzir resultados positivos no combate à criminalidade organizada é indispensável a conjugação de esforços entre a sociedade e o Estado. Nesta batalha sem fim, a participação de setores privados da sociedade, que esta lei indica no artigo $9^{\circ}$ e seu parágrafo único, passa a ser de vital importância. Contudo, é preciso raciocinar tendo em vista a realidade do nosso povo. Desejar que o universo constituído pelas pessoas jurídicas e físicas oneradas pela lei seja capaz de identificar as operações que 'possam constituir-se em sérios indícios dos crimes de lavagem'é, a meu ver, um sonho de concretude inatingível na proporção do que se proclama. É certo que esta tarefa poderá vir a ser desenvolvida com algum êxito em determinados setores, mormente pelas pessoas jurídicas razoavelmente estruturadas. Porém, o grosso das pessoas obrigadas a cumprir essas normas administrativas, com certeza, ainda que possam demonstrar boa vontade, pouco ou nada acrescentarão ao desiderato do legislador. ${ }^{15}$

Para Edson Pinto:

esta postura, adotada em diversos países, demonstra a clara incapacidade dos Estados em exercerem os controles sozinhos e, embora os órgãos oficiais de inteligência financeira façam recomendações indicando as espécies de operações e valores que devem ser mais atentamente observados, não possuem a plena capacidade de verificação que apregoam, causando embaraços ao cumprimento da Lei, pois a não aplicação das penalidades administrativas pela não comunicação de transações suspeitas (art.12) provoca nos chamados mercados um relaxamento natural e sem a participação ativa desses segmentos são utópicas as chances de êxito nas investigações e nas ações preventivas. ${ }^{16}$

\subsubsection{Normativos do Banco Central do Brasil}

Conforme já mencionado, a Lei no 9613/98 determina que cabe às autoridades competentes elaborar relação de operações que, por suas características, no que se refere às partes envolvidas, valores, forma de realização, instrumentos utilizados, ou pela falta de fundamento econômico ou legal, possam configurar indícios de crimes.

A Circular no 3461 do Bacen, publicada em 24 julho de 2009, além de consolidar regras anteriormente editadas, determinou o dever da pessoas sujeitas à Lei no 9613/98 de comunicar ao Coaf:

I - as operações realizadas ou serviços prestados cujo valor seja igual ou superior a $\mathrm{R} \$ 10.000,00$ (dez mil reais) e que, considerando as partes envolvidas, os valores, as formas de realização, os instrumentos utilizados ou a falta de fundamento econômico ou legal, possam configurar a existência de indícios dos crimes previstos na Lei no 9.613, de 1998;

15 Op. Cit., p. 306

16 Op. Cit., p.102 


\section{REVISTA ELETRÔNICA DA \\ FACULDADE DE DIREITO DE FRANCA \\ $w w w . r e v i s t a . d i r e i t o f r a n c a . b r$ \\ v. 6, n.1, dez/2012, ISSN: 1983-4225}

II - as operações realizadas ou serviços prestados que, por sua habitualidade, valor ou forma, configurem artifício que objetive burlar os mecanismos de identificação, controle e registro;

III - as operações realizadas ou os serviços prestados, qualquer que seja o valor, a pessoas que reconhecidamente tenham perpetrado ou intentado perpetrar atos terroristas ou neles participado ou facilitado o seu cometimento, bem como a existência de recursos pertencentes ou por eles controlados direta ou indiretamente;

IV - os atos suspeitos de financiamento do terrorismo.

Para auxiliar as instituições financeiras no atendimento a essas determinações, o Bacen, logo após a publicação da Lei n 9.613/98, editou a Carta-Circular n 2.826/98 que trouxe relação de operações e situações que podem configurar indício de ocorrência de crime de lavagem de dinheiro. O documento divide situações relacionadas com operações em espécie ou em cheques de viagem, com manutenção de contas correntes, com atividades internacionais, e com empregados das instituições e seus representantes.

Identificadas alguma situação com indício de ocorrência de crime de lavagem de dinheiro, a instituição financeira (entenda-se aqui o Diretor responsável, registrado no Bacen, pelo combate à lavagem de dinheiro, juntamente com um Comitê instituído para tal fim, ou sozinho), após análise valorativa dos fatos por área específica da instituição, levando em consideração as partes envolvidas, os valores, a forma de realização, os instrumentos utilizados, o fundamento econômico ou legal, a capacidade financeira presumida do cliente, decidirá pela comunicação ou não ao Coaf.

Recebidas informações acerca de movimentações financeiras, como já mencionado anteriormente, incumbe ao Coaf proceder à respectiva análise e determinar a comunicação às autoridades competentes, quando concluir pela existência de crimes, de fundados indícios de sua prática, ou de qualquer outro ilícito. Cabe ao presidente do Coaf oficiar às autoridades competentes, sempre que os exames concluírem pela existência de fortes indícios de irregularidades (Regimento Interno do Coaf, Portaria $n^{\circ} 330$, de 18 de dezembro de 1998).

A Lei $n^{\circ}$ 9.613/98 dispõe que deverão ser comunicadas aos órgãos competentes as situações que apresentem indícios de crimes, porém, há entendimento, como o expressado no HC N ${ }^{\circ}$ 0007683-90.2010.404.0000/SC - TRF $4^{\circ}$ Região, de que não compete ao Coaf efetuar investigação exaustiva para firmar convicção acerca de eventual prática delituosa, uma vez que o juízo que lhe compete é o de aparência, agindo o Coaf dentro do limite previsto pela 


\section{REVISTA ELETRÔNICA DA \\ FACULDADE DE DIREITO DE FRANCA \\ $w w w . r e v i s t a . d i r e i t o f r a n c a . b r$ \\ v. 6, n.1, dez/2012, ISSN: 1983-4225}

legislação de regência. A comunicação efetuada à autoridade competente, acerca de eventual prática ilícita, não vicia a prova decorrente produzida em investigação posterior.

Entretanto, o próprio TRF da $4^{\circ}$ Região no julgamento do HC N² 2008.04.00.032915-0 entendeu que se não constatada evidência de crime, não é permitido ao Coaf compartilhar informações obtidas dentro de suas atribuições legais (artigo 15 da Lei n ${ }^{\circ}$ 9.613/98), sob pena de, assim o fazendo, haver ilegalidade a ser reconhecida em sede de habeas corpus. Com efeito, o compartilhamento é exceção, que deve ser interpretada em sentido restrito, ou seja, não mais do que a norma autoriza. Desse modo, estarão assegurados os direitos de privacidade e intimidade, previstos constitucionalmente.

Além da comunicação de situações consideradas atípicas (indícios de crimes) regulada pelos normativos citados anteriormente, a Circular $n^{\circ}$ 3461/09 do Bacen obriga os bancos a comunicarem ao Coaf, dentre outras situações, depósito em espécie, saque em espécie e pedido de provisionamento para saque, de valor igual ou superior a $\mathrm{R} \$ 100.000,00$ (cem mil reais), independente de qualquer análise de atipicidade ou identificação de indício de crime.

Outro aspecto relevante é o monitoramento especial dispensado às pessoas consideradas politicamente expostas, as chamadas PPEs. A Circular $\mathrm{n}^{\mathbf{0}}$ 3461/09 do Bacen determina que os bancos coletem de seus clientes informações que permitam caracterizálos ou não como pessoas politicamente expostas (PPE) e identifiquem a origem dos fundos envolvidos nas transações dos clientes assim caracterizados.

Consideram-se pessoas politicamente expostas os agentes públicos que desempenham ou tenham desempenhado, nos últimos cinco anos, no Brasil ou em países, territórios e dependências estrangeiros, cargos, empregos ou funções públicas relevantes (PPE titular), assim como seus representantes, familiares e outras pessoas de seu relacionamento próximo (PPE Relacionado).

\section{LEI COMPLEMENTAR N N $^{\circ}$, SIGILO BANCÁRIO, INTIMIDADE E VIDA PRIVADA}

Exceções ao direito ao sigilo bancários, hipóteses de quebra ou transferência, encontram-se regulamentadas pelo legislador ordinário na Lei Complementar $\mathrm{n}^{\mathrm{o}} 105$, de 10.01.2001 que dispõe sobre o sigilo de operações de instituições financeiras.

O artigo $1^{\circ}$, parágrafo $3^{\circ}$, da Lei Complementar $n^{\circ} 105$ elenca situações em que não há violação do dever de sigilo, dentre as quais, destacamos "a comunicação, às autoridades 


\section{REVISTA ELETRÔNICA DA FACULDADE DE DIREITO DE FRANCA \\ $w w w . r e v i s t a . d i r e i t o f r a n c a . b r$ \\ v. 6, n.1, dez/2012, ISSN: 1983-4225}

competentes, da prática de ilícitos penais ou administrativos, abrangendo o fornecimento de informações sobre operações que envolvam recursos provenientes de qualquer prática criminosa".

Já o artigo $2^{\circ}$, parágrafo $6^{\circ}$, da mesma Lei reafirma as obrigações contidas na Lei $\mathrm{n}^{\circ}$ 9.613/98 e dispõe que o Banco Central do Brasil, a Comissão de Valores Mobiliários e os demais órgãos de fiscalização, nas áreas de suas atribuições, fornecerão ao Conselho de Controle de Atividades Financeiras - Coaf as informações cadastrais e de movimento de valores relativos às operações previstas no inciso I do artigo 11 da Lei n 9613/98 (indícios de crimes).

A comunicação de transações ou operações financeiras que constituam indícios de crimes (análise valorativa de uma pessoa ou comitê de acordo com a relação de situações editadas pelo órgão regulador) ao Coaf, conforme mandamentos da Lei $\mathrm{n}^{\circ}$ 9.613/98 e da Lei Complementar $\mathrm{n}^{\circ} 105$, colide com o direito ao sigilo bancário, à vida privada e à intimidade de um cliente? Ou esses direitos não são absolutos, como qualquer outro, e podem ceder ante interesses públicos relevantes?

Para Sérgio Carlos Covello, sigilo bancário é: a obrigação que têm os bancos de não revelar, salvo justa causa, as informações que venham a obter em virtude de sua atividade profissional". ${ }^{17}$

Nelson Abrão define o sigilo bancário como sendo:

a obrigação do banqueiro - a benefício do cliente - de não revelar certos fatos, atos, cifras ou outras informações de que teve conhecimento por ocasião do exercício de sua atividade bancária e notadamente aqueles que concernem a seu cliente, sob pena de sanções muito rigorosas civis, penais ou disciplinares. ${ }^{18}$

O sigilo bancário teria surgido em razão das exigências da atividade comercial, usado como técnica de captação, como atrativo da confiança dos clientes, ou seja, as pessoas ao depositarem seus valores à confiança de uma instituição financeira sentem-se seguras quanto à questão da confidencialidade. O sigilo bancário nasceu para proteger os interesses privados dos comerciantes, dos banqueiros e de seus clientes, mas, com o tempo, ganhou destaque de interesse público em função da importância que os sistemas bancário e de crédito passaram a ter no desenvolvimento econômico dos países. ${ }^{19}$

17 O Sigilo Bancário. São Paulo: Leud, 2001, p.83

18 Direito Bancário. $3^{\circ}$ Ed. São Paulo: Editora Revistas dos Tribunais, 1996, p.54

19 http://bdjur.stj.gov.br/xmlui/handle/2011/18649. Freitas, Paulo Henrique de Souza; Trecenti, Fernanda Eloísa. $O$ sigilo bancário e o direito à privacidade : constitucionalidade da lei complementar $n^{o}$ 105. Acesso em 17/07/2010. 


\section{REVISTA ELETRÔNICA DA \\ FACULDADE DE DIREITO DE FRANCA \\ www.revista.direitofranca.br \\ v. 6, n.1, dez/2012, ISSN: 1983-4225}

Para Arnoldo Wald:

o cidadão tem direito a manter em sigilo as informações sobre sua vida financeira obtidas pelos bancos, o que está ligado ao direito à privacidade, constitucionalmente protegido. A instituição bancária tem direito de manter segredo dos dados de seus clientes, pois a discrição faz parte do seu fundo de comércio, sendo uma forma de obter a confiança de terceiros. Também é obrigação do banco não noticiar as operações realizadas, correspondendo ao direito já mencionado do cliente. O sigilo bancário interessa, ainda, à sociedade, porque proporciona o bom funcionamento do sistema financeiro e o desenvolvimento da economia do país. ${ }^{20}$

A Constituição Federal de 1988 não fala expressamente em sigilo bancário, mas sim em proteção à intimidade e vida privada no Título II, "Dos Direitos e Garantias Constitucionais":

Art. $5^{\circ}$ Todos são iguais perante a lei, sem distinção de qualquer natureza, garantindo-se aos brasileiros e aos estrangeiros residentes no País a inviolabilidade do direito à vida, à liberdade, à igualdade, à segurança e à propriedade, nos termos seguintes:

(....)

$\mathrm{X}$ - são invioláveis a intimidade, a vida privada, a honra e a imagem das pessoas, assegurando o direito a indenização pelo dano material ou moral decorrente de sua violação.

Para o Supremo Tribunal Federal, segundo entendimento da maioria dos seus Ministros, o direito ao sigilo bancário constitui espécie de direito à privacidade ou intimidade, inerente à personalidade das pessoas, consubstanciado no art. $5^{\circ}$, inciso $\mathrm{X}, \mathrm{da} \mathrm{CF}^{21}$

$\mathrm{O}$ primeiro julgamento em que o STF enfrentou diretamente pedido de quebra de sigilo bancário foi na questão de ordem Petição 577/5/170 - $\mathrm{DF}^{22}$. O Ministro Carlos Velloso fundamentou no direito à privacidade o sigilo bancário, apontando sua característica de direito da personalidade:

O sigilo bancário protege interesses privados. É ele espécie de direito à privacidade,

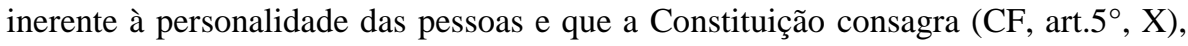
além de atender "a uma finalidade de ordem pública, qual seja a de proteção do sistema de crédito".

(...) Faço residir, portanto, no inciso $X$, do art. $5^{\circ}$, da Constituição, o sigilo bancário, que tenho como espécie de direito à privacidade.

No mesmo julgamento assinalou o Ministro Celso de Mello que:

A tutela jurídica da intimidade constitui - qualquer que seja a dimensão em que se projete - uma das expressões mais significativas em que se pluralizam os direitos da personalidade. Trata-se de valor constitucionalmente assegurado ( $\left.\mathrm{CF}, \operatorname{art} .5^{\circ}, \mathrm{X}\right)$,

20 Sigilo bancário e os direitos fundamentais. Cadernos de Direito Tributário e Finanças Públicas, São Paulo, v.6, n.22, p.15, jan./mar. 1998.

21 MARQUES, Karla Padilha Rebelo. Corrupção, dinheiro público e sigilo bancário: desconstruindo mitos. Porto Alegre: Nuria Fabris, 2008, p.79.

22 Pet.(questão de ordem) 577/5/170 - DF - Rel.: Min. Carlos Velloso - Reqte. Delgado de Polícia Federal - J. em 25/03/1992 - DJ 23/04/1993 - STF. 


\section{REVISTA ELETRÔNICA DA FACULDADE DE DIREITO DE FRANCA \\ www.revista.direitofranca.br \\ v. 6, n.1, dez/2012, ISSN: 1983-4225}

proteção normativa busca erigir e reservar, em favor do indivíduo - e contra a ação expansiva do arbítrio do Estado - uma esfera de autonomia intangível e indevassável pela atividade persecutória do Poder Público, apta a inibir e a vedar o próprio acesso dos agentes governamentais.

(...)

A quebra do sigilo bancário - ato que, por si só, revela extrema gravidade jurídica situa-se nesse contexto, em que valores contrastantes - como o princípio da autoridade, de um lado, e o postulado das liberdades públicas, de outro - guardam, entre si, nítidas relações de tensão dialética.

Impõe-se, portanto, que os agentes da persecutio criminis submetam-se à atuação moderadora e arbitral do Poder Judiciário, cujos órgãos, ponderando os interesses que se antagonizam, permitam ou não, o acesso das autoridades policiais às informações concernentes às operações, ativas e passivas, realizadas pelas pessoas sob investigação com as instituições financeiras.

A relevância do direito ao sigilo bancário - que traduz, na concreção do seu alcance, uma das projeções realizadoras do direito à intimidade - impõe, por isso mesmo, ao Poder Judiciário, cautela e prudência na determinação de ruptura da esfera de privacidade individual, que o ordenamento jurídico, em norma de salvaguarda, pretendeu submeter à cláusula tutelar de reserva.

Sem elementos fundados de suspeita, como a existência de indícios idôneos e reveladores de possível autoria de prática delituosa, não há como autorizar a disclosure das informações bancárias reservadas.

Também para parte da doutrina, o direito ao sigilo bancário encontra-se inserido dentro da esfera do direito à preservação da intimidade ou da privacidade.

Para Luciana Fregadolli:

o sigilo bancário protege interesses privados. É ele espécie de direito à privacidade, inerente à personalidade das pessoas e que a Constituição Federal consagra no art. $5^{\circ}$, X..." e "apenas o Poder Judiciário, por um de seus órgãos, pode eximir as instituições financeiras do dever de segredo em relação às matérias arroladas em lei". ${ }^{23}$

Cid Heráclito Queiroz, por sua vez, salienta que:

"os extratos e outros demonstrativos bancários, assim como as declarações de renda e de bens, são verdadeiramente retratos da intimidade do cidadão e as coleções desses documentos são como que álbuns reveladores da imagem íntima de cada um, ao longo da vida. ${ }^{24}$

\subsection{Intimidade e Vida Privada}

Os direitos à vida privada e à intimidade situam-se na $\mathrm{CF}$ entre os chamados "direitos individuais fundamentais" e, portanto, são considerados cláusulas pétreas, nos moldes do artigo 60, parágrafo $4^{\circ}$, inciso IV da CF.

23 O Direito à intimidade. In: Cadernos de Direito Constitucional e Ciência Política. São Paulo: Revista dos Tribunais. v. 19, p.233-237.

24 http://www.esaf.fazenda.gov.br/esafsite/Biblioteca/monografias/cristina_rodrigues_leitao.pdf. Sigilo Bancário. Cristina Rodrigues Leitão Prodanoff. QUEIROZ, Cid Heráclito. O sigilo bancário. In: Revista Forense. Rio de Janeiro. Jan/Mar 1995, v.329, p.44. Acesso em 17/07/2010. 


\section{REVISTA ELETRÔNICA DA FACULDADE DE DIREITO DE FRANCA \\ www.revista.direitofranca.br \\ v. 6, n.1, dez/2012, ISSN: 1983-4225}

Da leitura do texto constitucional é possível verificar que o legislador fez distinção entre intimidade e vida privada, contudo os conceitos são bastante imprecisos e há doutrinadores que entendem que tais institutos se confundem.

Edson Ferreira da Silva faz uso do termo intimidade para tratar indistintamente de ambos os bens jurídicos tutelados dada à "extrema dificuldade de se formular uma boa definição para algo de conteúdo tão impreciso, mutável, inconstante e diversificado, porque subordinado aos costumes e aos valores sociais, que se diferenciam em cada época e lugar". ${ }^{25}$

Entretanto, grande parte da doutrina prefere empregar o termo intimidade como uma esfera mais restrita da vida privada, como Tércio Sampaio Ferraz Júnior que diz:

a intimidade é o âmbito exclusivo que alguém reserva para si, sem nenhuma repercussão social, nem mesmo ao alcance da sua vida privada que, por mais isolada que seja, é sempre um viver entre os outros (na família, no trabalho, no lazer comum). Não há um conceito absoluto de intimidade. Mas é possível exemplificálo: o diário íntimo, o segredo sob juramento, as próprias convicções, as situações indevassáveis de pudor pessoal, o segredo íntimo cuja mínima publicidade constrange. Já a vida privada envolve a proteção de formas exclusivas de convivência. Trata-se de situações em que a comunicação é inevitável (em termos de relação de alguém com alguém que, entre si, trocam mensagens), das quais, em princípio são excluídos terceiros. Terceiro é, por definição, o que não participa, o que não troca mensagens, que está interessado em outras coisas. Numa forma abstrata, o terceiro compõe a sociedade, dentro da qual a vida privada se desenvolve, mas que com esta não se confunde. A vida privada pode envolver, pois, situações de opção pessoal (como a escolha do regime de bens no casamento) mas que, em certos momentos, podem requerer a comunicação de terceiros (na aquisição, por exemplo, de um bem imóvel). Por aí ela difere da intimidade, que não experimenta esta forma de repercussão. ${ }^{26}$

Para José Afonso da Silva:

não é fácil distinguir vida privada de intimidade. Aquela, em última análise, integra a esfera íntima da pessoa, porque é repositório de segredos e particularidades do foro moral e íntimo do indivíduo. Mas a Constituição não considerou assim. Deu destaque ao conceito, para que seja mais abrangente, como conjunto de modo de ser e viver, como direito de o indivíduo viver sua própria vida. Parte da constatação de que a vida das pessoas compreende dois aspectos: um voltado para o exterior e outro para o interior. A vida exterior, que envolve a pessoa nas relações sociais e nas atividades públicas, pode ser objeto das pesquisas e das divulgações de terceiros, porque é pública. A vida interior, que se debruça sobre a mesma pessoa, sobre os membros de sua família, sobre seus amigos, é a que integra o conceito de vida privada, inviolável nos termos da Constituição. ${ }^{27}$

Para a Constituição Federal de 1988, a intimidade corresponde a um âmbito mais restrito da vida privada, relaciona-se à parte da vida do indivíduo resguardável até mesmo dos

25 Direito à intimidade. São Paulo: Oliveira Mendes, 1998, pg. 37

26 http://www.terciosampaioferrazjr.com.br/?q=/publicacoes-cientificas/49. Sigilo de dados: o Direito à privacidade e os limites à função fiscalizadora do Estado. 24/08/2006. Acesso em 17/072010.

27 Curso de Direito Constitucional Positivo. $18^{\circ}$ Ed. São Paulo: Malheiros Editores, 200, p.211. 


\section{REVISTA ELETRÔNICA DA \\ FACULDADE DE DIREITO DE FRANCA \\ www.revista.direitofranca.br \\ v. 6, n.1, dez/2012, ISSN: 1983-4225}

que participam de sua privacidade (convicções pessoais, medos, angústias, desejos íntimos, etc).

Os que defendem a idéia de que o sigilo bancário, com a abrangência que lhe foi conferida pelo Supremo Tribunal Federal, encontra o seu fundamento nos direitos da personalidade (dignidade da pessoa humana) como uma manifestação da defesa do direito à intimidade ou privacidade dos indivíduos, asseguram que o homem afirma a própria personalidade através de seus bens materiais, sendo que o seu patrimônio interfere na sua projeção social e, assim, projeta a sua personalidade. ${ }^{28}$

Para outros estudiosos do assunto, como Paulo Henrique de Souza Freitas e Fernanda Eloísa Trecenti: "somente nos casos onde o acesso às informações bancárias puder realmente expor a vida privada dos clientes é que a proteção constitucional à privacidade e à intimidade recairá, também, sobre o sigilo bancário. ${ }^{29}$

\subsection{Supremacia do Interesse Público}

Diante do que já foi levantado no presente trabalho, a previsão na Lei n ${ }^{\circ}$ 9.613/98 e na Lei Complementar $n^{\circ} 105$ do dever de comunicação ao Coaf pelas instituições bancárias de situações identificadas na movimentação financeira dos clientes que configurem indícios de crimes, bem como a questão do sigilo bancário como expressão do direito constitucional à intimidade e à vida privada (artigo 5º inciso X, da Constituição Federal de 1988), devendo, por entendimento de parcela majoritária da doutrina e da jurisprudência dos tribunais, estar sujeito à reserva de jurisdição, de modo que a requisição de informações financeiras e bancárias deve ser sempre precedida de autorização judicial, é pertinente agora passar a discutir se há ou não violação do direito à intimidade e à vida privada no ato de comunicação ao Coaf de situações com indícios de crimes (consideradas atípicas, anormais ou suspeitas) pelas instituições bancárias.

A princípio, é possível considerar que a comunicação de indícios de crime (na prática operações consideradas atípicas ou anormais) efetuada pelos Bancos ao Coaf não se trata propriamente de quebra de sigilo bancário, já que os dados repassados não se tornam

28 http://www.esaf.fazenda.gov.br/esafsite/Biblioteca/monografias/cristina_rodrigues_leitao.pdf. Sigilo Bancário. Cristina Rodrigues Leitão Prodanoff. Acesso em 17/07/2010.

29 http://bdjur.stj.gov.br/xmlui/handle/2011/18649. Freitas, Paulo Henrique de Souza; Trecenti, Fernanda Eloísa. O sigilo bancário e o direito à privacidade : constitucionalidade da lei complementar $n^{o}$ 105. Acesso em 17/07/2010. 


\title{
REVISTA ELETRÔNICA DA FACULDADE DE DIREITO DE FRANCA \\ www.revista.direitofranca.br \\ v. 6, n.1, dez/2012, ISSN: 1983-4225
}

públicos, o que ocorre é a transferência de informações a autoridade devidamente instituída por lei para tratar do assunto. O Coaf, órgão competente pelo recebimento das informações, e seus servidores têm o dever de zelar pela manutenção do caráter confidencial das informações recebidas, sob pena de eles próprios incidirem em conduta delituosa.

Consta no "Relatório de Atividade 2009" do Coaf que os relatórios produzidos pelo Coaf, denominados Relatórios de Inteligência Financeira - RIF, são protegidos por sigilo, inclusive bancário, e têm como destinatárias as autoridades competentes para os procedimentos que julgarem cabíveis. A violação do sigilo do RIF, além de constituir crime, causa transtornos às entidades obrigadas por lei a fornecer informações ao Coaf, às próprias autoridades competentes e, em última análise, ao sistema de prevenção à lavagem de dinheiro e ao financiamento do terrorismo (PLD/FT) como um todo. ${ }^{30}$

Além disso, o próprio STF identifica o direito ao sigilo bancário como relativo, podendo ceder em face do interesse público, do interesse da justiça, do interesse social. $\mathrm{Na}$ existência de conflito entre princípios e/ou direitos constitucionais, esses não devem ser interpretados de forma absoluta, sendo cabível a restrição de determinado princípio e/ou direito, com base na ponderação de interesses, para dar espaço a outro de maior relevância no caso concreto.

Sobre o tema, esclarece José Paulo Baltazar Junior que:

\begin{abstract}
sendo certo que o sigilo financeiro não é um direito absoluto, hipóteses haverá nas quais informações ou documentos relativos a operações ativas e passivas ou serviços prestados por instituições financeiras poderão ser fornecidas sem que isso represente violação indevida. O próprio STF já decidiu que 'a quebra do sigilo bancário não afronta o art. $5^{\circ}$, X e XII, da CF' (Pleno, Rel. Min. Francisco Rezek, DJ 24/03/95). Na mesma linha, o Tribunal Constitucional Espanhol, ao assentar o princípio de que as atividades econômicas em geral não se encontram amparadas pelo direito à intimidade, admite a limitação, sempre que atingidos fins legítimos e respeitado o princípio da proporcionalidade.

Tais limitações legais decorrem da circunstância de ser o sigilo financeiro objeto de um direito relativo, estabelecido essencialmente em função de interesses privados, de modo que são possíveis limitações, especialmente quando fundadas no interesse público.

Como visto, o sigilo financeiro tem fundamento constitucional na proteção da vida privada, consagrada no inciso $\mathrm{X}$ do art. $5^{\circ}$ da Carta de 1988 . Firmou-se, ainda, a posição de que o direito fundamental à vida privada tem a natureza de princípio, havendo a possibilidade de sua restrição, desde que respeitado o preceito da proporcionalidade. De tudo isso, é possível afirmar o cabimento da restrição ao sigilo, ainda que ancorado no referido direito fundamental, uma vez observadas a necessidade, a adequação e a proporcionalidade em sentido estrito da medida restritiva. ${ }^{31}$
\end{abstract}

30 https://www.coaf.fazenda.gov.br/conteudo/publicacoes/relatorios-coaf/RelatorioAtividades2009.pdf.

Relatório de Atividade 2009. Acesso em 13/10/2010.

31 Sigilo Bancário e Privacidade. Porto Alegre: Ed. Livraria do Advogado, 2005, p. 90 


\title{
REVISTA ELETRÔNICA DA FACULDADE DE DIREITO DE FRANCA \\ www.revista.direitofranca.br \\ v. 6, n.1, dez/2012, ISSN: 1983-4225
}

Robert Alexy entende que os direitos fundamentais possuem caráter de princípios que por muitas vezes colidem, sendo necessária uma solução ponderada em favor de um deles. Para o autor a distinção entre regras e princípios é uma das colunas-mestras do edifício da teoria dos direitos fundamentais. Tanto regras como princípios são normas, porque ambos dizem o que deve ser, mas há uma diferença qualitativa entre esses preceitos. Princípios seriam mandamentos de otimização, ou seja, são normas que ordenam que algo seja realizado na maior medida possível dentro das possibilidades jurídicas e fáticas existentes. Já as regras são normas que são sempre satisfeitas ou não satisfeitas. Regras contêm determinações no âmbito daquilo que é fática e juridicamente possível. ${ }^{32}$

As colisões entre princípios devem ser solucionadas de forma completamente diversa de um conflito entre regras. Se dois princípios colidem - o que ocorre, por exemplo, quando algo é proibido de acordo com um princípio e, de acordo com o outro, permitido -, um dos princípios terá que ceder. Isso não significa que será inválido, na verdade o que ocorre é que um dos princípios tem precedência em face do outro sob determinadas condições. No caso concreto os princípios têm pesos diferentes e os princípios com o maior peso têm precedência. $^{33}$

A obrigação de comunicação de situações com indícios de crime (situações consideradas atípicas ou anormais) pelos bancos ao Coaf evidencia uma relação de tensão entre o dever estatal de garantir a operacionalidade do Direito Penal, a proteção da ordem sócio econômica, do sistema financeiro nacional e da administração da justiça (princípio da supremacia do interesse público que está implícito na Constituição Federal), e o interesse do cidadão de ter direito ao sigilo de suas informações financeiras que é, conforme entendimento, um direito constitucionalmente consagrado.

\section{Como afirma Robert Alexy:}

\begin{abstract}
essa relação de tensão não pode ser solucionada com base em uma precedência absoluta de um desses deveres, ou seja, nenhum desses deveres goza, "por si só, de prioridade. O "conflito" deve, ao contrário, ser resolvido "por meio de um sopesamento entre os interesses conflitantes". O objetivo desse sopesamento é definir qual dos interesses - que abstratamente estão no mesmo nível - tem maior peso no caso concreto. ${ }^{34}$
\end{abstract}

32 Alexy, Robert. Teoria dos Direitos Fundamentais. Tradução Virgílio Afonso da Silva. São Paulo: Editora Malheiros, 2008, p.85/90

33 Idem.Ibidem., p.93/94

34 Op. Cit., p.95 


\section{REVISTA ELETRÔNICA DA FACULDADE DE DIREITO DE FRANCA \\ www.revista.direitofranca.br \\ v. 6, n.1, dez/2012, ISSN: 1983-4225}

E continua o autor dizendo que:

um princípio restringe as possibilidades jurídicas de outro. Essa situação não é
resolvida com a declaração de invalidade de um dos princípios e com sua
conseqüiente eliminação do ordenamento jurídico. Ela tampouco é resolvida por
meio da introdução de uma exceção a um dos princípios, que seria considerado, em
todos os casos futuros, como uma regra que ou é realizada, ou não é. A solução para
essa colisão consiste no estabelecimento de uma relação de precedência
condicionada entre os princípios, com base nas circunstâncias do caso concreto. ${ }^{35}$

Ainda segundo Robert Alexy, há uma conexão entre a teoria dos princípios e a máxima da proporcionalidade (denominada com freqüência como "princípio da proporcionalidade") que é verificada pelos critérios de adequação do meio utilizado para a persecução do fim, necessidade desse meio utilizado e proporcionalidade em sentido estrito mandamento do sopesamento propriamente dito (ponderação). Princípios são mandamentos de otimização em face das possibilidades jurídicas e fáticas. A máxima da proporcionalidade em sentido estrito, ou seja, exigência de sopesamento (ponderação), decorre da relativização em face das possibilidades jurídicas. Já a máxima da necessidade e da adequação decorrem da natureza dos princípios como mandamentos de otimização em face das possibilidades fáticas.

A análise da adequação precede a da necessidade, que, por sua vez, precede a da proporcionalidade em sentido estrito. A aplicação da regra da proporcionalidade pode esgotar-se, em alguns casos, com o simples exame da adequação do ato estatal para a promoção dos objetivos pretendidos. Em outros casos, pode ser indispensável a análise acerca de sua necessidade. Por fim, nos casos mais complexos, e somente nesses casos, deve-se proceder à análise da proporcionalidade em sentido estrito. ${ }^{36}$

O critério adequação significa utilizar o meio mais adequado (apto) para a persecução do fim desejado. Adequado no sentido de que seria o meio que conseguisse promover (fomentar) o fim almejado não infringindo tanto o outro princípio como outros meios poderiam vir a infringir. ${ }^{37}$

O fim almejado pela Lei $\mathrm{n}^{\circ}$ 9.613/98 é o combate à lavagem de dinheiro no país (proteção da ordem socioeconômica, do sistema financeiro, da administração da justiça), e um dos meios considerados adequados para fomentar esse fim (otimizar o princípio da supremacia do interesse público) é a observância da movimentação financeira dos clientes de uma instituição financeira. Assim, a referida Lei prevê que nos casos de identificação de 


\section{REVISTA ELETRÔNICA DA FACULDADE DE DIREITO DE FRANCA \\ $w w w . r e v i s t a . d i r e i t o f r a n c a . b r$ \\ v. 6, n.1, dez/2012, ISSN: 1983-4225}

indícios de crime (situações suspeitas ou atípicas), os bancos deverão obrigatoriamente comunicar o fato ao Coaf. Esse meio é considerado o mais apto, adequado a promover o combate à lavagem de dinheiro sem infringir de forma absoluta os direitos à privacidade e intimidade, já que não expõe publicamente o sigilo bancário dos clientes.

Já o critério da necessidade significa que não há outro meio menos restritivo com um custo menor, ou seja, o meio não é necessário se se dispõe de um mais suave ou menos restritivo. Duas medidas podem ser adequadas para a realização do objetivo, porém a medida necessária é aquela menos gravosa ao indivíduo.

Como afirma Virgilio Afonso da Silva: "um ato estatal que limita um direito fundamental é somente necessário caso a realização do objetivo perseguido não possa ser promovida, com a mesma intensidade, por meio de outro ato que limite, em menor medida, o direito fundamental atingido." 38

A transferência de informações sobre a movimentação financeira de um cliente, efetuada pelos bancos ao Coaf, é considerada o meio menos gravoso encontrado pelo legislador para combater a lavagem de dinheiro, medida que afeta menos intensamente a realização daquilo que a norma de direito fundamental (sigilo bancário, intimidade, privacidade) com estrutura de princípio exige.

Por último o critério da proporcionalidade em sentido estrito seria o mandamento do sopesamento propriamente dito (ponderação). Na ponderação, deve-se ter em conta a intensidade e a importância da intervenção em um direito fundamental. Por esse critério coloca-se as consequiências jurídicas dos princípios em colisão numa balança (metáfora do peso), a fim de precisar qual delas é racionalmente mais importante no caso concreto. ${ }^{39}$

O exame da proporcionalidade em sentido estrito consiste em um sopesamento entre a intensidade da restrição ao direito fundamental atingido e a importância da realização do direito fundamental que com ele colide e que fundamenta a adoção da medida restritiva. ${ }^{40}$

Como afirma Robert Alexy: "quanto maior for o grau de não-satisfação ou de afetação de um princípio, tanto maior terá que ser a importância da satisfação do outro". ${ }^{41}$

A lei do sopesamento deve seguir três passos: a princípio avaliação do grau de nãosatisfação ou afetação de um dos princípios (intensidade de intervenção); depois avaliação da

38 Op. Cit., p.39

39 http://www.conjur.com.br/2007-mar-02/robert_alexy_teoria_principios_regras. JÚDICE, Monica Pimenta. Robert Alexy e a sua teoria sobre os princípios e regras, 2/3/2007. Acesso em 20/07/2010.

40 SILVA, Virgilio Afonso da. Op. Cit., p.41

41 Op. Cit., p.593 


\section{REVISTA ELETRÔNICA DA \\ FACULDADE DE DIREITO DE FRANCA \\ $w w w . r e v i s t a . d i r e i t o f r a n c a . b r$ \\ v. 6, n.1, dez/2012, ISSN: 1983-4225}

importância da satisfação do princípio colidente, ou seja, a importância da satisfação do princípio oposto; no último passo deve ser avaliado se a importância da satisfação do princípio colidente justifica a afetação ou não-satisfação do outro principio, isto é, se a importância da satisfação de um direito fundamental justifica a não satisfação do outro. ${ }^{42}$

O grau de afetação à intimidade e vida privada de um cliente no que diz respeito à comunicação pelos bancos ao Coaf de indícios de crime, identificados na movimentação financeira, não pode ser considerado alto, a intervenção não é absoluta, visto que não há quebra de sigilo bancário propriamente, as informações não são divulgadas ao público, elas são transferidas a um órgão responsável e obrigado a manter sigilo.

Essa transferência de informações financeiras ao Coaf é justificada em razão da importância da satisfação do princípio da supremacia do interesse público, enquanto interesse da sociedade, consubstanciado na noção de justiça (proteção da ordem econômico-financeira, da administração da justiça e combate à criminalidade econômica). O Estado tem o dever de combater atividades ilícitas como corrupção, desvio de recursos públicos e lavagem de dinheiro, e por isso deve utilizar instrumentos adequados para investigação e repressão. $\mathrm{O}$ sigilo bancário que, por um lado, serve como garantia de direitos constitucionais do cidadão, motiva, por outro, criminosos a utilizarem o sistema financeiro nacional para lavagem de dinheiro.

As diversas discussões no tocante à ocultação de divisas e remessa de dinheiro proveniente de atividades ilícitas é uma problemática que mobiliza as nações do mundo inteiro. Periodicamente são apresentadas novas propostas legislativas e documentos de orientação, pelos diversos organismos internacionais que se dedicam ao assunto (GAFI, ONU, GAFISUD, etc), ou por países economicamente importantes, principalmente os EUA, que têm por objetivo aperfeiçoar a fiscalização, o controle e registro das operações financeiras, a fim de combater o uso do sistema financeiro para ações ilícitas e até mesmo para o financiamento do terrorismo. O Brasil, por razões econômicas e pela posição atual que ocupa no cenário mundial atual, não fica alheio a essas orientações e recomendações.

De um lado está o dever estatal de apurar e prevenir crimes, aplicar adequadamente o direito penal, proteger o sistema financeiro e econômico, a administração da justiça e de outro o interesse do cliente em ter seu sigilo bancário preservado. Entretanto, a defesa da preservação do sigilo bancário enquanto interesse individual deve ceder ante a satisfação do 


\section{REVISTA ELETRÔNICA DA \\ FACULDADE DE DIREITO DE FRANCA \\ www.revista.direitofranca.br \\ v. 6, n.1, dez/2012, ISSN: 1983-4225}

princípio da supremacia do interesse público, ou seja, ante o interesse maior na investigação voltada ao combate à criminalidade, sobretudo, se envolve desvio ou malversação de recursos públicos, financiamento do terrorismo e lavagem de dinheiro. ${ }^{43}$

\section{DADOS ESTATÍSTICOS}

Os dados sobre os resultados dos relatórios que o Coaf encaminha às autoridades competentes, o grau de utilidade das informações prestadas e os eventuais procedimentos instaurados a partir deles, além do número de inquéritos, denúncias e condenações pelo crime de lavagem de dinheiro no Brasil são limitados e imprecisos.

Em 2005 o Coaf publicou os seguintes dados ${ }^{44}$ :

\begin{tabular}{|l|r|r|r|r|r|r|r|r|r|}
\hline ANO & $\mathbf{1 9 9 8}$ & $\mathbf{1 9 9 9}$ & $\mathbf{2 0 0 0}$ & $\mathbf{2 0 0 1}$ & $\mathbf{2 0 0 2}$ & $\mathbf{2 0 0 3}$ & $\mathbf{2 0 0 4}$ & $\mathbf{2 0 0 5}$ & TOTAL \\
\hline Inquéritos Policiais & 0 & 12 & 23 & 64 & 32 & 198 & 310 & 359 & 998 \\
\hline Ações Penais & 3 & 6 & 1 & 4 & 9 & 26 & 74 & 48 & 171 \\
\hline Total de Réus & 125 & 55 & 30 & 75 & 83 & 336 & 617 & 652 & 1973 \\
\hline Total de Réus Condenados & 2 & 1 & 0 & 0 & 9 & 172 & 87 & 90 & 361 \\
\hline
\end{tabular}

Em 2005 o Coaf recebeu 158.617 comunicações consideradas atípicas dos setores econômicos obrigados, porém, de acordo com o quadro acima, no mesmo ano apenas 359 inquéritos foram instaurados.

Também é relevante mostrar a evolução dos dados estatísticos das primeiras Varas especializadas de São Paulo, $2^{\circ}$ e $6^{\circ}$ Varas Federais, Criadas a partir do Provimento $n^{\circ} 238$, de 27 d agosto de 2004, do Tribunal Regional Federal da $3^{\circ}$ Região ${ }^{45}$ :

2a VARA

\begin{tabular}{|l|r|r|r|r|r|}
\hline TIPO DE AÇÃO & out.2004 & mar.2005 & out.2005 & out.2006 & out.2007 \\
\hline Ação Criminal & 332 & 384 & 371 & 321 & 338 \\
\hline Inquérito Policial & 556 & 736 & 831 & 948 & 1021 \\
\hline Procedimentos Criminais Diversos & 251 & 302 & 340 & 423 & 631 \\
\hline TOTAL & $\mathbf{1 1 3 9}$ & $\mathbf{1 4 2 2}$ & $\mathbf{1 5 4 2}$ & $\mathbf{1 6 9 2}$ & $\mathbf{1 9 9 0}$ \\
\hline
\end{tabular}

6 $^{\text {a VARA }}$

\begin{tabular}{|l|r|r|r|r|r|}
\hline TIPO DE AÇÃO & out.2004 & mar.2005 & out.2005 & out.2006 & out.2007 \\
\hline Ação Criminal & 390 & 412 & 434 & 419 & 495 \\
\hline
\end{tabular}

43 MARQUES, Karla Padilha Rebelo. Op. Cit., p.171.

44 PINTO, Edson. Op. Cit., p. 105

45 DE SANCTIS, Fausto Martin. Op. Cit., p. 176 


\section{REVISTA ELETRÔNICA DA \\ FACULDADE DE DIREITO DE FRANCA \\ www.revista.direitofranca.br \\ v. 6, n.1, dez/2012, ISSN: 1983-4225}

\begin{tabular}{|l|r|r|r|r|r|} 
Inquérito Policial & 600 & 861 & 818 & 904 & 905 \\
\hline Procedimentos Criminais Diversos & 379 & 420 & 409 & 461 & 640 \\
\hline TOTAL & $\mathbf{1 3 6 9}$ & $\mathbf{1 6 9 3}$ & $\mathbf{1 6 6 1}$ & $\mathbf{1 7 8 4}$ & $\mathbf{2 0 4 4}$ \\
\hline
\end{tabular}

Os dados de fevereiro de 2008 demonstram existir na $2^{\text {a }}$ Vara 2066 feitos, sendo 386 ações penais e na $6^{\text {a }}$ Vara 2139, sendo 791 ações penais.

Para complementar, em 28 de agosto de 2010 foi publicada a seguinte matéria no jornal "O Globo" 46 :

\section{Lavagem de dinheiro: sentença ainda é rara; doze anos após lei específica, apenas}

\section{7 processos chegaram ao final}

BRASÍLIA - Há 12 anos no papel, a lei que pune a lavagem de dinheiro engatinha para ser posta em prática: apenas 17 processos resultaram em condenações transitadas em julgado - com uma sentença definitiva, sem possibilidade de recurso. Lavagem é a tentativa de dar aparência legal a recursos obtidos por meios ilícitos. Portanto, a prática prevê um crime anterior. Segundo o corregedor do Conselho Nacional de Justiça (CNJ), ministro Gilson Dipp, especialista no assunto, o crime antecedente mais comum no Brasil é a corrupção. Mas, entre as condenações definitivas, a maior parte é por tráfico de drogas.

$\mathrm{O}$ número de sentenças transitadas em julgado é pequeno, especialmente se comparado à quantidade de ações. Só no ano passado, as varas estaduais e federais tinham 905 inquéritos e 355 ações penais sobre lavagem de dinheiro. Houve 111 julgamentos. Nos Tribunais de Justiça e nos Tribunais Regionais Federais, foram julgadas 607 ações sobre o tema. Ao fim do ano, outras 539 aguardavam decisão.

Punições em primeira instância não passam de ficção

A contabilidade sobre lavagem de dinheiro no Brasil é escassa. Não se sabe, por exemplo, qual o crime cometido antes da lavagem em todos os processos com sentença definitiva. Quatro tratam de tráfico internacional cometido por organização criminosa. E um de crime contra o sistema financeiro. Na semana passada, o Gafi (Grupo de Ação Financeira), que monitora a lavagem de dinheiro e o financiamento ao terrorismo no mundo, cobrou esses dados do Brasil. O CNJ prometeu organizálos. Mas é pouco provável que sejam formatados os dados dos processos já julgados. Também não há o número de condenações de 2009. Só nas varas especializadas da Justiça Federal havia 112 ações, das quais 63 foram julgadas. Destas, 39 foram pela condenação e 24, pela absolvição dos réus. Foram condenadas 45 pessoas - mais do que o dobro do ano anterior. Em 2008, foram julgados 94 processos nas varas especializadas, dos quais 47 resultaram em condenação e 47, em absolvição. Foram condenados 21 réus.

As punições determinadas pela primeira instância não passam de ficção: na maioria das vezes, o réu recorre ao tribunal no estado. Se a condenação for mantida, há possibilidade de apelo ao Superior Tribunal de Justiça e, em alguns casos, ao Supremo Tribunal Federal. É difícil um processo chegar ao fim. No ano passado, havia apenas sete recursos do gênero no STJ e nenhum foi julgado.

Para Gilson Dipp, o pequeno número de condenações deve-se à complexidade desse tipo de processo e à quantidade excessiva de recursos judiciais:

- A grande crítica dos organismos internacionais é o número pequeno de condenações com trânsito em julgado no Brasil sobre lavagem de dinheiro. ...

Existem no país 22 varas especializadas em lavagem de dinheiro em 15 unidades da federação, com 36 juízes. ....

46 http://oglobo.globo.com/pais/mat/2010/08/28/lavagem-de-dinheiro-sentenca-ainda-rara-doze-anos-apos-leiespecifica-apenas-17-processos-chegaram-ao-final-917502427.asp. Acesso em 21/10/2010. 


\title{
REVISTA ELETRÔNICA DA FACULDADE DE DIREITO DE FRANCA \\ www.revista.direitofranca.br \\ v. 6, n.1, dez/2012, ISSN: 1983-4225
}

\begin{abstract}
As tabelas do CNJ revelam que aumentaram os julgamentos nos tribunais de segunda instância, federais e estaduais. Em 2007, foram 531; em 2008, 593, e em 2009, 607. Os julgamentos também aumentaram nas varas de primeira instância: 316 em 2008 e 355 em 2009.

No Rio de Janeiro, no ano passado, havia quatro ações penais nas quatro varas especializadas. Duas foram julgadas - uma resultou em absolvição e a outra, na condenação de duas pessoas. No TRF da 2 Região, que atende Rio e Espírito Santo, não houve julgamentos de ações de lavagem de dinheiro em 2007, nem em 2008. No ano passado, foram julgados dois casos.

$\mathrm{Na}$ Justiça Estadual do Rio, os números são um pouco mais expressivos. Nas varas da primeira instância foram julgadas sete ações penais em 2007, seis em 2008 e nove em 2009. O Tribunal de Justiça do Rio não julgou nenhuma ação de lavagem de dinheiro em 2007, 2008 ou 2009.
\end{abstract}

Em decorrência de ações de monitoramento e análises realizadas pelo Coaf, no período entre 2003 e 2009, as autoridades de persecução (Ministério Público e Polícia Federal) bloquearam, com autorização judicial, cerca de $\mathrm{R} \$ 1,9$ bilhão em contas-correntes, fundos de investimentos e previdências privadas pertencentes a pessoas investigadas por crimes

Por ser a lavagem de dinheiro um crime transnacional, sua detecção, em muitos casos, depende da troca de informações entre as UIFs de diferentes países, o que torna a cooperação institucional, quando rápida e eficaz, um importante instrumento na produção de inteligência financeira. Cada UIF deve estar autorizada por lei a trocar informações de inteligência financeira com as congêneres estrangeiras. Em particular, deve ter a capacidade de cooperar e trocar informações, por iniciativa própria ou a pedido das autoridades competentes.

\section{CONCLUSÃO}

Neste trabalho foi abordada a colisão entre o sigilo bancário, levando em conta entendimento que considera este direito como espécie de direito à intimidade e privacidade, consubstanciado no artigo $5^{\circ}$, inciso $\mathrm{X}$, da Constituição Federal, e o princípio da supremacia do interesse público que, por sua vez, está implícito no ordenamento constitucional brasileiro.

A obrigação de comunicação pelos bancos ao Coaf de situações com indícios de crimes (situações consideradas atípicas ou anormais), conforme determina a Lei $n^{\circ}$ 9,613/98, evidencia a relação de tensão entre o interesse público e o dever estatal de garantir a operacionalidade do Direito Penal, a proteção da ordem sócio econômica, do sistema financeiro nacional e da administração da justiça (princípio da supremacia do interesse 


\section{REVISTA ELETRÔNICA DA FACULDADE DE DIREITO DE FRANCA \\ www.revista.direitofranca.br \\ v. 6, n.1, dez/2012, ISSN: 1983-4225}

público), e o interesse do cidadão em ter direito ao sigilo de suas informações financeiras e sua intimidade e privacidade preservadas.

Essa relação de tensão não é solucionada invalidando um dos princípios ou declarando qualquer deles como absoluto. Este conflito é resolvido por meio de um sopesamento entre os interesses conflitantes. Existe uma conexão entre a teoria dos princípios (os direitos fundamentais possuem caráter de princípios) e a máxima da proporcionalidade que é verificada pelos critérios da adequação, necessidade e a proporcionalidade em sentido estrito da medida restritiva.

O fim almejado pela Lei $n^{\circ}$ 9.613/98 é o combate à lavagem de dinheiro (proteção da ordem socioeconômica, do sistema financeiro, da administração da justiça), e um dos meios considerados adequados para fomentar esse fim (otimizar o princípio da supremacia do interesse público) é a observância da movimentação financeira dos clientes de uma instituição e a comunicação das operações com indícios de crime a um órgão responsável e legalmente instituído para tal fim (Unidade de Inteligência), esse meio pode ser considerado o mais apto, adequado a promover o combate à lavagem de dinheiro sem infringir de forma absoluta os direitos à privacidade e intimidade, já que não expõe publicamente os dados financeiros do cliente.

A transferência de informações ao Coaf também pode ser considerada o meio menos gravoso encontrado pelo legislador para combater a lavagem de dinheiro, medida que afeta menos intensamente a realização daquilo que a norma de direito fundamental com estrutura de princípio exige, ou seja, proteção do sigilo bancário, do direito à intimidade e privacidade da pessoa.

Ainda, levando-se em conta o último critério, proporcionalidade em sentido estrito, o sopesamento entre a intensidade da restrição ao direito fundamental atingido e a importância da realização do direito fundamental que com ele colide e que fundamenta a adoção da medida restritiva, é possível verificar que o grau de afetação à intimidade e vida privada de um cliente no que diz respeito à comunicação pelos bancos ao Coaf de indícios de crime (situações atípicas) observadas na movimentação financeira, não poder ser considerado alto, a intervenção não é absoluta, como já mencionado, as informações não são divulgadas ao público, elas são transferidas a um órgão responsável e obrigado a manter sigilo.

E essa comunicação é justificada em razão da importância da satisfação do princípio da supremacia do interesse público, enquanto interesse da sociedade, consubstanciado na 


\section{REVISTA ELETRÔNICA DA FACULDADE DE DIREITO DE FRANCA \\ $w w w . r e v i s t a . d i r e i t o f r a n c a . b r$ \\ v. 6, n.1, dez/2012, ISSN: 1983-4225}

noção de justiça (proteção da ordem econômico-financeira, da administração da justiça e combate à criminalidade econômica). O Estado tem o dever de combater atividades ilícitas como corrupção, desvio de recursos públicos e lavagem de dinheiro, e por isso deve utilizar instrumentos adequados e incisivos para investigação e repressão desses crimes.

A lavagem de dinheiro é uma medida utilizada para dar aparência lícita a recursos adquiridos de forma ilícita (fruição das vantagens da infração). É um delito derivado de outro e, para usufruir do produto do crime, a criminalidade tem se aparelhado e utilizado métodos sofisticados para lavar os recursos ilícitos e, apesar de muitas vezes não ocorrer violência física, expressada por meio de sangue e armas, isso causa sérios danos à sociedade (Exemplos: financiamento do tráfico de drogas e armas e até do terrorismo, desvio de recursos públicos que poderiam ser utilizados para a educação e saúde, facilitação do crime e da violência) o que obriga uma intervenção estatal mais contundente e fundamenta a adoção de medidas restritivas.

Vale ressaltar que, de acordo com os dados obtidos junto ao Coaf, as obrigações e restrições impostas pela Lei $n^{\circ}$ 9.613/98 têm alcançado resultados satisfatórios no combate à lavagem de dinheiro no Brasil.

Entre 1998 e 2009, o Coaf recebeu cerca de 3,2 milhões de comunicações dos setores obrigados, desse total foram recebidas do setor financeiro 103.395 comunicações em razão de operações consideradas atípicas (indícios de crimes) e 1.247.558 em razão das operações em espécie (saque, depósito ou provisionamento para saque de valor igual ou superior a $\mathrm{R} \$ 100$ mil).

No período compreendido entre 2003 e 2009, o Coaf produziu 8,3 mil RIFs (Relatório de Inteligência Financeira), relacionando 171,7 mil comunicações e mais de 60,7 mil pessoas.

A cooperação entre o Coaf e outras instituições resultou em mais de 10,5 mil intercâmbios de informações, no período entre 2003 e 2009, com destaque para o Ministério Público (3,5 mil), Polícias (3,3 mil), Judiciário (1,3 mil) e Unidades de Inteligência Financeira (1,3 mil).

Além disso já foram realizados 1,6 mil intercâmbios de informações entre o Coaf e Unidades de Inteligência Financeira estrangeiras, entre 2003 e 2009, sendo 573 nos últimos três anos.

Em decorrência de ações de monitoramento e análises realizadas pelo Coaf, no período entre 2003 e 2009, as autoridades de persecução (Ministério Público e Polícia 


\section{REVISTA ELETRÔNICA DA FACULDADE DE DIREITO DE FRANCA \\ www.revista.direitofranca.br \\ v. 6, n.1, dez/2012, ISSN: 1983-4225}

Federal) bloquearam, com autorização judicial, cerca de $\mathrm{R} \$ 1,9$ bilhão em contas-correntes, fundos de investimentos e previdências privadas pertencentes a pessoas investigadas por crimes de lavagem de dinheiro ou outros crimes conexos, no Brasil e no exterior.

Entretanto, não há dados atuais que evidenciem o número de Relatório de Inteligência Financeira, produzidos pelo Coaf, que depois de encaminhados às autoridade competentes resultaram em inquéritos policiais e ações penais.Os dados são imprecisos e muitas vezes não confiáveis, situação inclusive apontada pelo GAFI como falha no sistema de prevenção e combate à lavagem de dinheiro no Brasil.

Conforme matéria publicada, em 28/08/2010, no "O Globo", desde o advento da Lei $\mathrm{n}^{\circ}$ 9.613/98, apenas 17 processos judiciais resultaram em condenações transitadas em julgado, com apenas uma sentença definitiva sem possibilidade de recurso. $\mathrm{O}$ número de sentenças transitadas em julgado sobre lavagem de dinheiro é pequeno no Brasil, especialmente se comparado à grande quantidade de ações e de comunicações repassadas ao Coaf, e essa é a grande crítica dos organismos internacionais e da própria sociedade que é a maior interessada no combate à criminalidade.

Após 12 anos da publicação da Lei no 9613/98 ainda não há condenações como anseia a sociedade, porém, houve avanços no combate à lavagem de dinheiro no Brasil, como a criação de varas especializadas, maior agilidade no bloqueio de bens, repatriação de valores remetidos ao exterior de forma ilegal, ações da Polícia Federal, etc. E, embora não tão expressivos e como a sociedade deseja, é possível concluir do que foi estudado neste trabalho, que esses avanços obtidos com o advento da Lei $n^{\circ}$ 9.613/98 justificam e fundamentam a restrição aos direitos a intimidade e privacidade de um cliente, a relativização do sigilo bancário, face a satisfação da supremacia do interesse público.

\section{RFERÊNCIAS BIBLIOGRÁFICAS}

ABRÃO, Nelson. Direito Bancário. $3^{\circ}$ Ed. São Paulo: Editora Revistas dos Tribunais, 1996.

ALEXY, Robert. Teoria dos Direitos Fundamentais. Tradução Virgílio Afonso da Silva. São Paulo: Editora Malheiros, 2008

BALTAZAR JUNIOR, José Paulo. Sigilo Bancário e Privacidade. Porto Alegre: Ed. Livraria do Advogado, 2005.

BARROS, Marco Antônio de. Lavagem de capitais e obrigações civis correlatas. Com comentário, artigo por artigo, à Lei 9613/98, São Paulo: Revista dos Tribunais, 2004. 


\section{REVISTA ELETRÔNICA DA FACULDADE DE DIREITO DE FRANCA \\ $w w w . r e v i s t a . d i r e i t o f r a n c a . b r$ \\ v. 6, n.1, dez/2012, ISSN: 1983-4225}

COVELLO, Sérgio Carlos. O Sigilo Bancário. São Paulo: Leud, 2001.

DE SANCTS, Fausto Martin. Combate à Lavagem de Dinheiro. Campinas/SP: Millenium Editora, 2008.

FERRAZ JR., Tércio Sampaio. Sigilo de dados: o Direito à privacidade e os limites à função fiscalizadora do Estado. 24/08/2006. Disponível em: http://www.terciosampaioferrazjr.com.br/?q=/publicacoes-cientificas/49. Acesso em 17/072010.

FREGADOLLI, Luciana. O Direito à intimidade. In: Cadernos de Direito Constitucional e Ciência Política. São Paulo: Revista dos Tribunais. v. 19.

FREITAS, Paulo Henrique de Souza; Trecenti, Fernanda Eloísa. O sigilo bancário e o direito à privacidade: constitucionalidade da lei complementar $n^{\circ}$ 105. Disponível em: http://bdjur.stj.gov.br/xmlui/handle/2011/18649. Acesso em 17/07/2010.

JÚDICE, Monica Pimenta. Robert Alexy e a sua teoria sobre os princípios e regras, 2/3/2007. Disponível em: http://www.conjur.com.br/2007-mar02/robert_alexy_teoria_principios_regras. Acesso em 20/07/2010.

LILLEY, Peter. Lavagem de dinheiro: negócios ilícitos transformados em atividades legais. São Paulo: Futura, 2001.

MAIA, Rodolfo Tigre. Lavagem de Dinheiro. $2^{\circ}$ Edição. São Paulo: Malheiros Editores, 2007.

MARQUES, Karla Padilha Rebelo. Corrupção, dinheiro público e sigilo bancário: desconstruindo mitos. Porto Alegre: Nuria Fabris, 2008.

PINTO. Edson. Lavagem de Capitais e Paraísos Fiscais. São Paulo: Atlas, 2007.

PRODANOFF, Cristina Rodrigues Leitão. Sigilo Bancário. Disponível em:

http://www.esaf.fazenda.gov.br/esafsite/Biblioteca/monografias/cristina_rodrigues_leitao.pdf. Acesso em 17/07/2010.

QUEIROZ, Cid Heráclito. O sigilo bancário. In: Revista Forense. Rio de Janeiro. Jan/Mar 1995, v.329, p.44. Acesso em 17/07/2010.

SILVA, Edson Ferreira da. Direito à intimidade. São Paulo: Oliveira Mendes, 1998, pg. 37

SILVA, José Afonso da. Curso de Direito Constitucional Positivo. $18^{\circ}$ Ed. São Paulo: Malheiros Editores, 2000.

SILVA, Virgilio Afonso da. O proporcional e o razoável. Revista dos Tribunais 798 (2002). 


\section{REVISTA ELETRÔNICA DA FACULDADE DE DIREITO DE FRANCA \\ www.revista.direitofranca.br \\ v. 6, n.1, dez/2012, ISSN: 1983-4225}

VELOSO, Ricardo Ribeiro. Origem Histórica do crime de lavagem de dinheiro - no Brasil e no mundo. Disponível em:

http://www.mundojuridico.adv.br/sis_artigos/artigos.asp?codigo=777. Acesso em 21/04/2010.

WALD, Arnoldo. Sigilo bancário e os direitos fundamentais. Cadernos de Direito Tributário e Finanças Públicas, São Paulo, v.6, n.22, p.15, jan./mar. 1998.

Coaf - estrutura. Disponível em:

https://www.coaf.fazenda.gov.br/conteudo/institucional/o-coaf/estrutura-do-coaf/. Acesso em 15/05/2010.

Coaf - relatório de atividades. Disponível em:

https://www.coaf.fazenda.gov.br/conteudo/publicacoes/relatorios-

coaf/RelatorioAtividades2009. p.11 e 12. Acesso em 12.10.2010

GAFI/FATF. Members and Observers. Disponível em: http://www.fatfgafi.org/pages/0,3417,en_32250379_32236869_1_1_1_1_1,00.html.

Acesso em 21/04/2010.

Guía de Estudio para El Exame de Certificación CAMS - Cuarta Edición - Publicación de la ACAMS

Lavagem de dinheiro: sentença ainda é rara; doze anos após lei específica, apenas 17 processos chegaram ao final. Disponível em:

http://oglobo.globo.com/pais/mat/2010/08/28/lavagem-de-dinheiro-sentenca-ainda-rara-dozeanos-apos-lei-especifica-apenas-17-processos-chegaram-ao-final-917502427.asp. Acesso em 21/10/2010.

Que es lavado de dinero. Disponível em:

http://www.lavadodinero.com/QueEsLavado/QueEsLavado_Etapas.aspx. Acesso em $12 / 04 / 2010$.

Sobre Lavagem de Dinheiro. O que é. Disponível em:

https://www.coaf.fazenda.gov.br/conteudo/sobre-lavagem-de-dinheiro-1. Acesso em $12 / 04 / 2010$

What is a FIU? Disponível em: http://www.egmontgroup.org/about/what-is-an-fiu. Acesso em $15 / 05 / 2010$. 